\title{
Researches on the Separation of Heterogeneous Systems
}

\author{
M. F. Ştefănescu ${ }^{1}$, I.A. Sima ${ }^{2} \&$ M. Constantin ${ }^{3}$ \\ ${ }^{1}$ Professor Dr. Eng., ${ }^{2}$ PhD Student, ${ }^{3}$ Sl. Dr. Eng., Faculty of Mechanical Engineering and Mechatronics, \\ Department of Thermodynamics, Engines, Thermal and Refrigerating Equipment's, University Politehnica of Bucharest, \\ Romania.Email: i.mihaelaconstantin@gmail.com ${ }^{3}$
}

DOI: http://doi.org/10.38177/ajast.2021.5104

Copyright: (C2021 M.F.Ştefănescu et al. This is an open access article distributed under the terms of the Creative Commons Attribution License, which permits unrestricted use, distribution, and reproduction in any medium, provided the original author and source are credited.

\section{ABSTRACT}

The paper presents the methods used to separate heterogeneous systems, the fields of technique where it is used and the factors that must be taken into account when choosing the method, respectively the depollution installation. In the case of mechanical gas separation, a constructive solution of a cyclone is presented and its inclusion in a battery of cyclones that aims to separate the coal dust from the air, the allowed limit being $15 \mathrm{mg} / \mathrm{m} 3 \mathrm{of}$ air. For a cylindrical cyclone, the equilibrium equations of the main forces acting on a solid particle entering the cyclone are written; the cyclone efficiency and the parameters that influence the cyclone efficiency are defined. At the end of the paper, the axonometric scheme for the dust removal installation at the Borzești II Electro-Thermal Power Plant and the obtained results in the case of a scientific researches contract are presented.

Keywords: Biphasic media, Cyclones, Gas dedusting installations.

\section{INTRODUCTION}

Depollution of gases (air or flue gases) means their separation from solid particles suspended in that gas.

The methods used to separate heterogeneous systems can be divided into the following main groups [1] [2]:

I. Mechanical or dry gas separation, in which the sedimentation of the particles is performed under the action of mechanical forces.

The separation (purification, dusting, mechanical purification) can be performed by:

a) Sedimentation chambers also called deposition chambers, where the sedimentation of particles is done under the action of gravitational force;

b) Cyclones, where the particles sedimentation is done under the action of centrifugal force.

II. Wet gases separation by passing them through a layer of liquid or by spraying with liquid.

Wet separation can be performed with:

a) Scrubbers;

b) Wet surface devices;

c) Foam devices.

III. The gases filtration through porous materials, which does not allow particles suspended in the gas to pass through.

Gas filtration can be performed with bag filters.

IV. Electrical gases separation by sedimentation of gas-dispersed particles in a high voltage electric field. 


\section{AJAST}

Asian Journal of Applied Science and Technology (AJAST) Volume 5, Issue 1, Pages 30-38, January-March 2021

Electrical separation can be done with:

a) Tubular electric filters;

b) Electric plate filters;

c) Tubular electric filters with plates.

The separation methods I, II, III, IV, in the art, are found in the following cases:

- In coal crushing stations, coal bunkers, coal bunkers, concrete preparation stations.

- Conveyor belts with sand, coal, cement, etc.

The methods presented above use equipment's that ensures compliance with the republican labor protection rules; thus, for coal dust, the maximum concentration allowed in the air is $15 \mathrm{mg} / \mathrm{m}^{3}$.

The following factors must be taken into account when choosing the method and type of gas depollution system:

a) For gas particles: density, composition, humidity, electrical conductivity, flammability.

b) For the gas in which contains the particles: density, viscosity, temperature, pressure, humidity.

c) For gas circulation: volumetric flow rate, pressure drop, particle concentration in the gas.

d) For the installation to be purchased: capture efficiency, service life, maintenance costs, possibilities to use the captured particles.

e) For the operation of the installation: the necessary space, necessary utilities (water, electricity), the volume of investment.

The quality of the separation installation is carried out on the basis of measurements on the parameters: capture efficiency, content of particles in the cleaned gas, minimum particle size that can be retained by the separating element, service life between two cleanings, risk of fire or explosion.

\section{MECHANICAL SEPARATION}

Next, only point b) called "cyclones" will be analyzed from group I.

\section{The cyclone, the constructive solution and its operation.}

For large flow rates of impure gases (air + coal dust, air + sawdust, air + various dusts) the most commonly used method is to use cyclones.

Cyclones are often used because it does not contain moving parts, maintenance is easy, it has a long service life [3][4]. The cyclone consists of a cylindrical body (1) followed by a conical tube (2) and a purified gas exhaust pipe (3) arranged inside the cylindrical part (1) (figure 1).

The impure, dusty gas, is brought into the cyclone through the pipe (4), located tangential to the cylinder. In this way the gas is forced to perform a rotational movement around the exhaust pipe inside the cyclone. During the rotational motion of the gas a centrifugal force develops under the action of which solid particles which are 


\section{ADAST}

Asian Journal of Applied Science and Technology (AJAST)

Volume 5, Issue 1, Pages 30-38, January-March 2021

suspended in the gas and have a mass greater than the mass of the gas particles are oriented from the center to the periphery and hit the cylinder wall, then fall into the conical part of the cyclone [5][6].

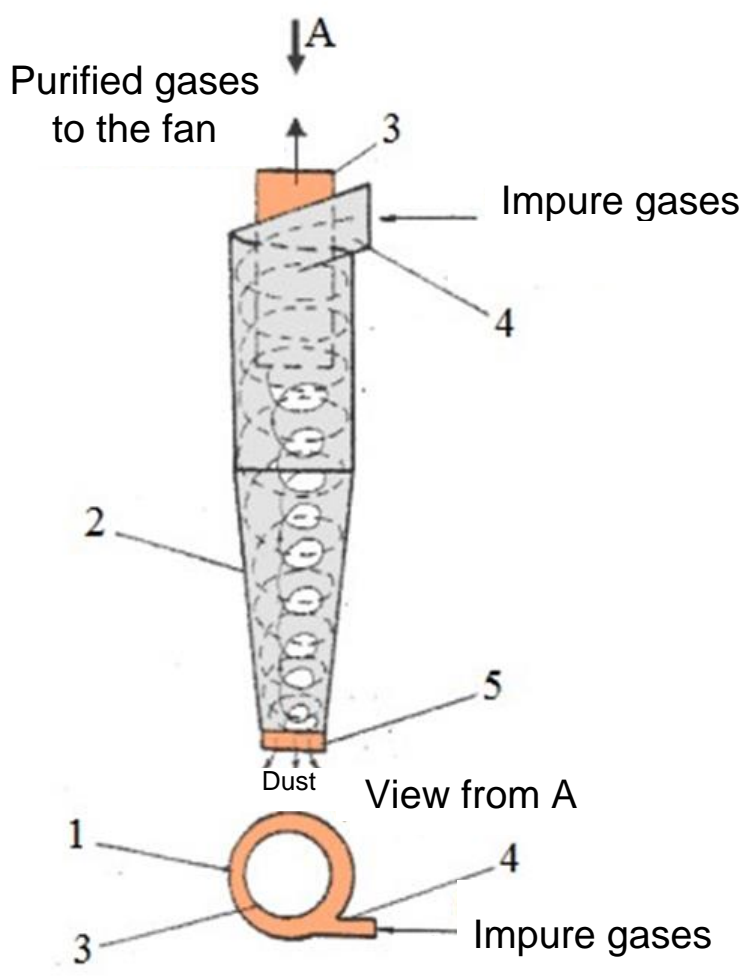

Fig.1. Cyclone Operating Scheme

\section{1 - Cylindrical Body; 2 - Conical Part; 3 - Exhaust Pipe; 4 - Intake Pipe; 5 - Particle Evacuation Nozzle}

The purified gas is discharged from the cyclone through the pipe (3), and the solid particles deposited in the conical part of the device are removed through the nozzle (5).

- In many cases it is advisable to use cyclones with direct passage, which have small dimensions, at relatively low resistance coefficients.

Some types of such cyclones also provide sufficiently high purification coefficients. The purification efficiency depends considerably on the suction degree of the gas mixture with dust from the cyclone bunker.

- Cyclones with direct passage assemble well in groups (batteries), especially cyclones with pallet rotation elements.

The resistance coefficient of the direct passage cyclone battery remains almost the same as for the isolated cyclone.

-Wet gas purification equipment's are often used to increase the purification degree of suspended particles of gas (air). Improving uptake in wet treatment equipment's is achieved by irrigating the gas flow rate with a liquid, sprayed by injectors or with a film of water, created on the surface of the gas treatment equipment.

\section{CYCLONES BINDING}

Cyclones used in dedusting installations can be bound in several ways to make cyclone batteries. 


\section{AJAST}

Asian Journal of Applied Science and Technology (AJAST)

Volume 5, Issue 1, Pages 30-38, January-March 2021

The following are distinguished:

a) connecting the cyclones in parallel, with horizontal intake at the same level;

b) connecting the cyclones in parallel, with horizontal intake in steps;

c) bounding cyclones in series.

The most used binding scheme is (a) (figure 2).

The dust collected from each cyclone is collected in a bunker and periodically discharged as the bunker is filled with coal dust [7] [8] [9].

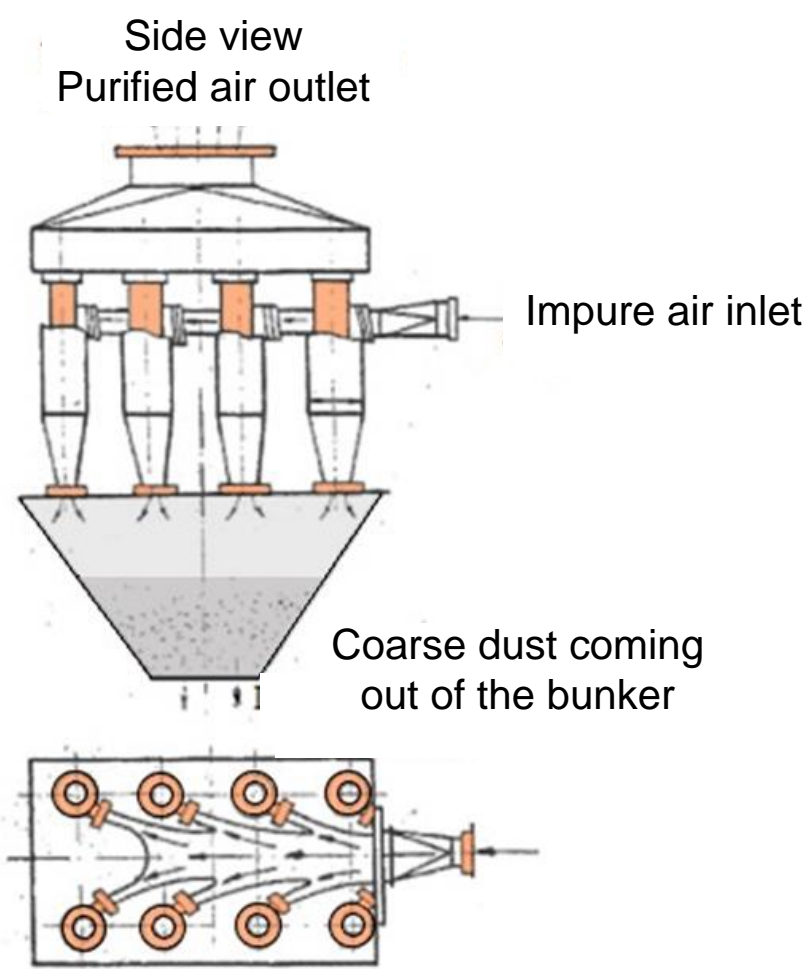

Top view

Fig.2. Binding Cyclones in Parallel

at the Same Level

The purified air is sucked in by a fan.

\section{THE FORCES ACTING ON A PARTICLE IN THE CYCLONE}

A mixture of air and solid particles enters the cyclone through pipe (1); under the action of centrifugal force the mixture describes a circle (2) (figure 3); subsequently, under the action of friction between the particles and the inner wall of the cyclone, the particles speed will decrease.

Under the effect of the weight of the particles the initial circle (2) becomes a helical motion. For the first circle (2) neither the Archimedean force $\left(\rho_{\text {air }}<<\rho_{p}\right)$ nor the inertia force of the particle is taken into account. As a result, the balance of forces on the $\mathrm{Ox}$ and $\mathrm{Oz}$ axis will be written [10]: 


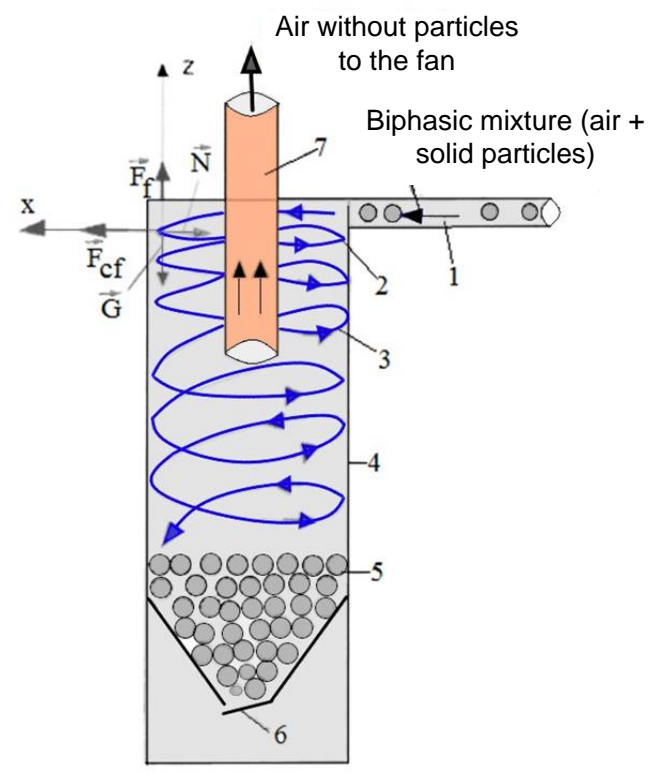

Fig.3. Cyclone Calculation Notes

1 - Supply Pipe with Biphasic Mixture; 2 - Circle Described by the First Particles Entering the Cyclone; 3 The Trajectory of a Particle in the Cyclone; 4 - Cyclone; 5 - Separate Particles; 6 - Flap for Particle Evacuation; 7 - Exhaust Air Duct to the Fan

The relations from mechanics,

$\sum\left(F_{i}\right)_{O x}=0 \rightarrow(\mathbf{1})$

becomes:

$F_{c f}-N=0 \rightarrow(2)$

$\sum\left(F_{i}\right)_{O z}=0 \rightarrow$

becomes:

$F_{f}-G=0 \rightarrow$ (4)

These two equations (2) and (4) determine the motion of the particle on the first circle in the cyclone when the helical motion does not yet occur (Figure 3).

\section{CYCLONE RESISTANCE, CYCLONE EFFICIENCY}

Increasing the concentration of suspended particles in the fluid decreases the resistance of the cyclone. This is explained by a number of factors: the reduction of fluid turbulence in the presence of particles suspended in it; reducing the amount of energy consumed for the transport of solid (or liquid) particles and reducing the amount of energy consumed for the rotation of the fluid; the effect of additional braking of the rotational movement of the fluid by the solid particles that deposit on the walls of the cyclone. The higher the concentration of suspended particles in the fluid within certain limits, the lower the resistance of the cyclone. 


\section{AJAST}

Asian Journal of Applied Science and Technology (AJAST)

Volume 5, Issue 1, Pages 30-38, January-March 2021

The resistance of the cyclone decreases substantially as the fluid rotation in the outlet connection decreases. This is done by installing either special steering blades before the outlet connection or an annular diffuser at the outlet of the connection. The annular diffuser is efficient both in the operation of the cyclone with the flow rate output in a large volume and in the operation in the network. It is not advisable to use the steering blades and the ring diffuser at the same time (figure 4). The maximum reduction of the cyclone resistance is also given by the snail which attenuates the tangential component and which allows to change at the same time the change of the flow direction by $90^{\circ}$. An ordinary elbow can also be used to change the direction of the fluid. When installing the elbow with a $90^{\circ}$ bend angle and $\mathrm{R} / \mathrm{d}=1.5$ in the immediate vicinity of the cyclone, its resistance does not increase. Only when the elbow is located far behind the cyclone (at distance $1 / \mathrm{d}>12$ ) should its additional strength be considered.

In practice, the cyclone efficiency $(\eta)$ is calculated as the ratio of concentrations [2]:

$\eta=\frac{C_{0}-C}{C_{0}} \rightarrow$

$\mathrm{C}_{0}$ - the concentration of gas particles at the entrance to the cyclone $\left[\mathrm{mg} / \mathrm{m}^{3}\right]$;

$\mathrm{C}-$ the concentration of gas particles at the exit of the cyclone $\left[\mathrm{mg} / \mathrm{m}^{3}\right]$.

The efficiency of the cyclone is higher the larger its diameter, but as the diameter increases the degree of purification decreases. Therefore, when the amount of purified gas is large, it is more appropriate to replace the large isolated cyclones with a group of smaller cyclones or with a battery of cyclones. The latter differs from a group of cyclones not only by the considerably smaller dimensions of the elements of the cyclones, but also by construction. In particular, special steering devices (rosettes with blades at an angle of $25^{\circ}-30^{\circ}$ ) to the axis of the cyclone or helical blades (figure 4).

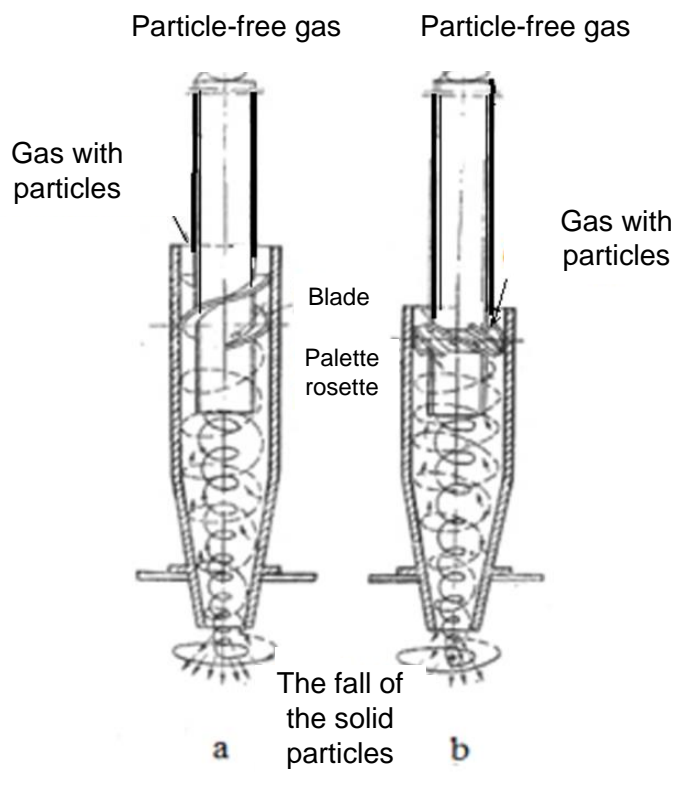

Fig.4. Cyclone Battery Elements

a - With Helical Blades; b - With Rosette 
The total hydraulic resistance of the cyclones in the group or in the battery includes not only the resistance of the elements of the cyclone itself, but also of the supply and discharge portions. In addition, the total resistance also takes into account the influence of the reinforcement conditions in the cyclone-type elements.

\section{THE SCHEME AND THE OPERATING PRINCIPLE OF A DRY DUST REMOVAL INSTALLATION}

A dry dust removal installation (figure 5) comprises: absorption hoods, transport pipes of the mixture of air + coal dust, a fan, a bunker for the coal dust.

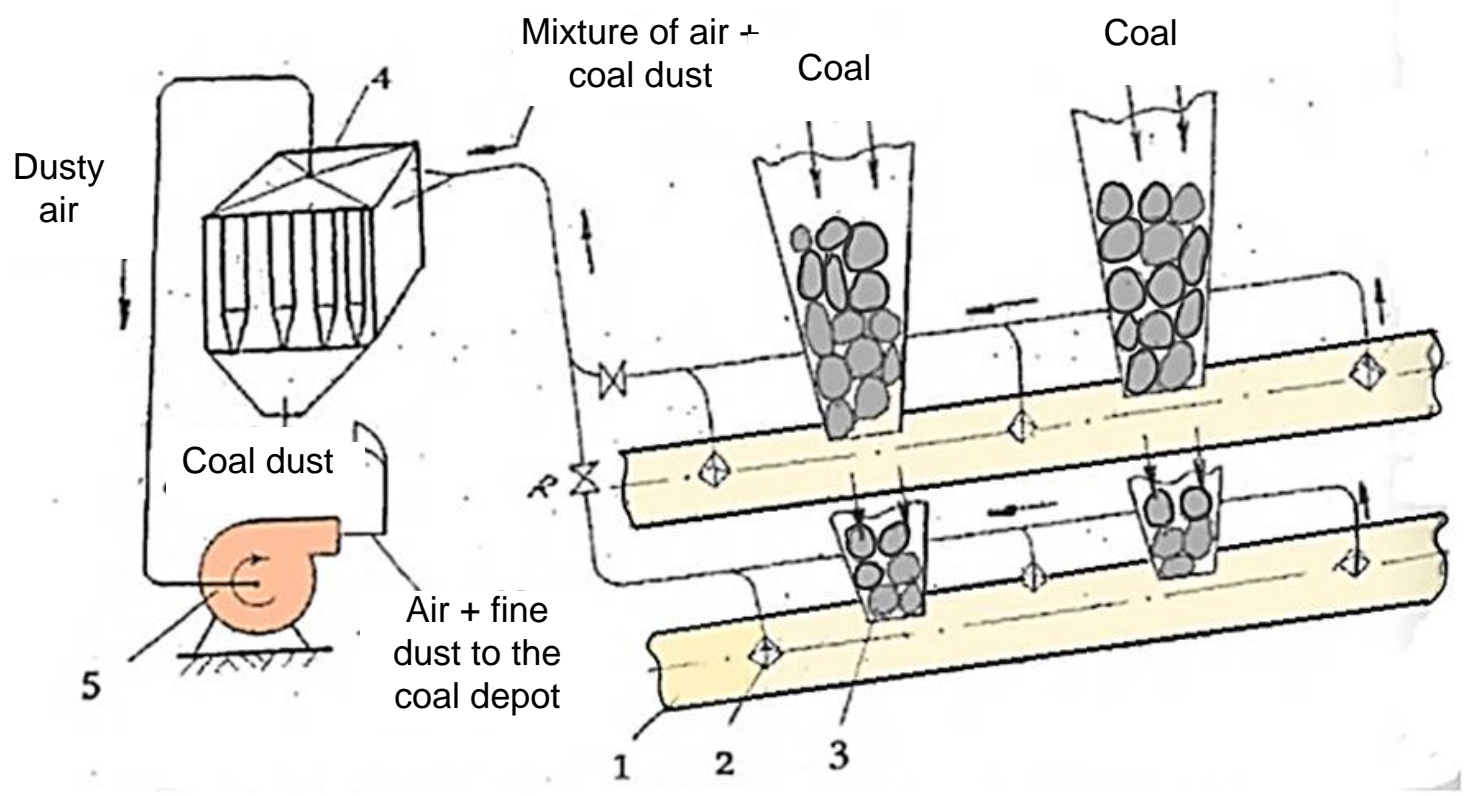

Fig.5. The Scheme of the Dry Dust Removal Installation with Cyclone Batteries

\section{1 - Conveyor Belt; 2 - Absorption Hood; 3 - Discharge Hopper on the Belt; 4 - Battery of Cyclones; 5 - Fan}

In order to reduce the dust emissions from the coal crushing station from CET Borzești II, a cyclone dust removal installation was implemented. The most important dust releases occur at the conveyor belts B-3a and B-3b, i.e., at the points of coal falling from the crusher on the belt or at its discharge from one belt to another [7].

So, there is the issue of suction, transport and separation of the mixture (air + coal dust) released at the conveyor belts. The suction hoods of the mixture (air + dust) which is sucked up by the cyclone bacterium are mounted near the coal drop points on the belt (figure 5). Inside the cyclone battery, the mixture is separated into two parts: the coarse dust is collected in the lower part of the battery (in the bunker), and the purified air is further sucked into the fan and evacuated to the coal depot; this is because the air blown back to the fan also contains very fine particles of coal dust $(\mathrm{d}<0.5 \mathrm{~mm})$ that will be deposited gravitationally in the coal deposit.

Figure 5 shows the general axonometric diagram of the dust removal installation with cyclone batteries [7].

Each battery has eight cyclones by the operation of which, a quantity of $2.5 \mathrm{~m}^{3} / \mathrm{h}$ of coal dust was collected in the coal bunker.

This quantity is reintroduced into the furnace of the steam boilers for combustion. 


\section{CONCLUSIONS}

1. Dry dust extraction installations are most commonly used because it has better reliability and easy maintenance.

2. From what is presented in the paper, it is found that the essential elements of a dry dust removal installation are the absorption hoods and cyclones.

3. When choosing the depollution system, the nature of the parameters of the biphasic mixture entering the installation must be taken into account.

4. The theoretical and experimental researches carried out in the laboratories of the Faculty of Mechanical and Mechatronics Engineering of University Politehnica of Bucharest, allowed the successful fulfilment of the scientific researches contract indicated in the references of the paper at position 7.

\section{Declarations}

\section{Source of Funding}

This research did not receive any specific grant from funding agencies in the public, commercial, or not-for-profit sectors.

\section{Competing Interests Statement}

The authors declare no competing financial, professional and personal interests.

\section{Consent to participate}

\section{Not Applicable}

\section{Consent for publication}

We declare that we consented for the publication of this research work.

\section{Availability of data and material}

Authors are willing to share data and material according to the relevant needs.

\section{REFERENCES}

1) Băran, N., Răducanu, P., ș.a., Colecţia Bazele Termodinamicii tehnice, vol. 3, Termodinamică Tehnică, Editura POLITEHNICA PRESS, Bucureşti, 2010

2) Voicu, V., Tehnica desprăfuirii aerului, Editura Tehnică, Bucureşti, 1988.

3) Florea, Julieta, Robescu, D., Hidrodinamica instalațiilor de transport hidropneumatic și de depoluare a apei și a aerului, Editura Didactică și Pedagogică, București, 1982.

4) Bratu, E., Operații și utilaje în industria chimică, vol. 1, vol. 2, Editura Tehnică, bucurești, 1969.

5) Tcacenco, V., Stanciu, C., Instalaţii de ventilare mecanică, Partea I, Microclimatul incintelor inchise, Litografia U.P.B., Bucureşti, 1996. 
6) Voicu, V., Casian, E., Bărăscu, I., Realizări recente în combaterea poluării atmosferei în industrie, editura Tehnică, Bucureşti, 1977.

7) *** Contract de cercetare științifică nr. 17-8-6/18.08.1998, I.P.B. cu tema "Soluții pentru reducerea concentrațiilor de praf de cărbune din centralele electrice la nivelul concentrațiilor și dispersiilor maxime admise", Beneficiar I.E. Borzești.

8) Slot, R. E., Terminal velocity formula for objects in a viscous fluid, Journal of Hidraulic Research, vol. 22, nr. 4, 1984 , p. $235-245$.

9) Dănescu, Al., Băran, Gh., Băran, N., Cercetări de laborator privind viteza de cădere a particulelor de praf de cărbune, Energetica, nr. 6, 1987, p. 265-268.

10) Idelcik, I.E., O metodike eksperimentalnogo opredeleniia ghidravliceskogo soprotivleniia ţiklonov, în Vodosnabjenie i sanitarnaia tehnika, 1969, nr.8, p. 21-25. 